\title{
Performance Appraisal; Application of Victor Vroom Expectancy Theory
}

\author{
Sania Abdul Rehman*, Sana Sehar, Muhammad Afzal
}

Lahore School of Nursing, the University of Lahore Pakistan

\author{
DOI: $10.36348 /$ sjnhc.2019.v02i12.008 \\ | Received: 05.12.2019 | Accepted: 15.12.2019 | Published: 28.12.2019 \\ *Corresponding author: Sania Abdul Rehman
}

\section{Abstract}

A performance evaluation is a regular analysis of the job performance of an employee and the overall contribution to an organization. It evaluates employees' skills, achievements and lacking. The performance assessment process of employees is essential for organizations to boost the productivity of employees and improve their results. Employees are less motivated in government and private hospitals. Employees and organization did not meet each other expectations. Victor Vroom develops theory of expectancy in 1964 which applied in this scenario. Vroom stated that three major factors determine the person motivation: expectancy, instrumentality and valence. Performance appraisal used as motivational tool and it is necessary for staff sustainability. Organization should do performance evaluation of employees and give feedback according to their work. Motivation is very important to enhance employee organizational commitment, resulting in higher productivity levels. Rewards are also some of the key strategies to strengthen the motivation of employees to use their best capabilities to develop innovative ideas that could improve organizational performance.

Keywords: Performance Appraisal, Expectancy Theory, Motivation, Evaluation.

Copyright @ 2019: This is an open-access article distributed under the terms of the Creative Commons Attribution license which permits unrestricted use, distribution, and reproduction in any medium for non-commercial use (NonCommercial, or CC-BY-NC) provided the original author and source are credited.

\section{INTRODUCTION}

Performance appraisal is a process or system of an organization to access the level of performance of their employees [1]. Organization are run and steered by people and their labors. It is through people goals are set and objectives realized depending on the performance of its members. The ability of an organization to measure the performance of its member is the vital source of an organization. Behavior on task is the result of performance of an employee, which can be observed and evaluated. Through combination of quantity, quality, time and cost performance of members can be measured. Evaluate the personality is the procedure that refer to the performance appraisal [2].

In the field of performance management, performance appraisal is a widely discussed. The performance appraisal system arises from the nature of the current business environment. The need of performance appraisal is to achieve the organizational goal. Ability to innovate is more increasingly digital competitive environment and organization [3].

\section{CASE SCENARIO}

Employees are less motivated in the Government and Private hospitals. They did not show interest to work. If they put effort or best deliver services, organization did not respond to their services in terms of reward. Staff performance did not evaluate. This will reduce staff performance and productivity. As a result, hospitals will not gain benefit and it will reduce the quality of services. Employees and hospitals did not meet each other expectations.

\section{Vroom's Expectancy Theory \\ Victor Vroom developed the expectancy theory of motivation in 1964. The theory is based on the assumption that our behavior is based on selecting consciously from a range of possible substitutes. The behavior that we choose will always be the one that maximizes our satisfaction and minimizes our stress, according to Expectancy Theory.}




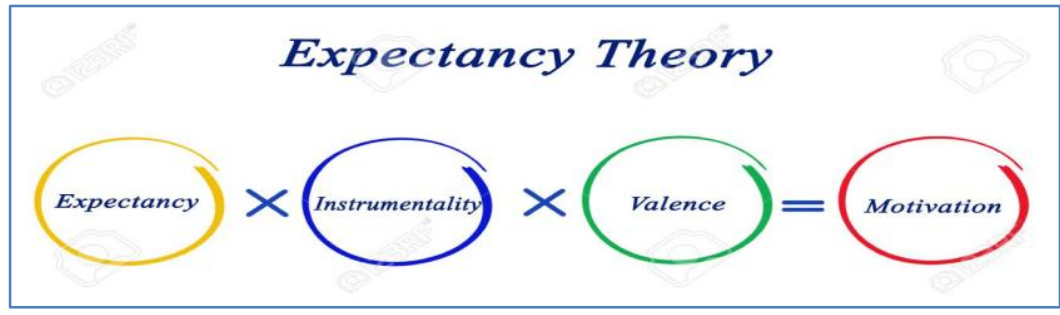

Three major factors that determines person's motivation

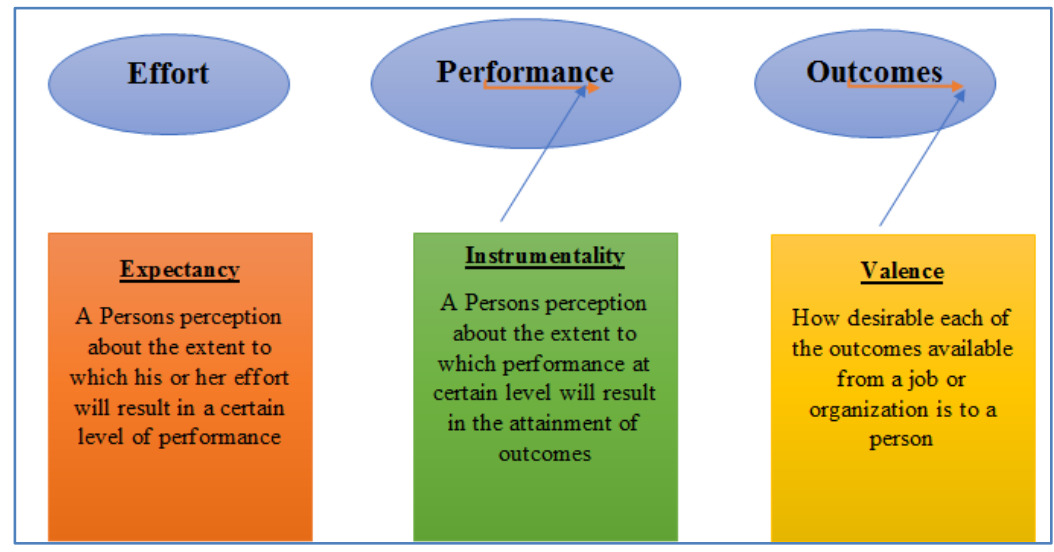

\section{Expectancy}

Expectancy is about employee's expectation from their own efforts and the relation to good performance. Part of expectation is his level of difficulty. An organization should respond to this by identifying factors that can inspire the employee to give the best possible performance. Such factors can include equipment, education or help from a boss who strengthens the morale of his employees. Victor Vroom says that more effort usually leads to better results. Employees can be encouraged to make an effort if they complete their mission correctly and efficiently by giving them reward.

\section{Instrumentality}

Each employee is an instrument that contributes to the results of the service. From this viewpoint, it is not difficult to grasp instrumentality. The performance of the employee is good enough to achieve the desired outcome. This can be promoted by an organization by delivering on promises of extra incentives such as bonuses or promotion. Transparency is a vital aspect for instrumentality throughout the reward process.

\section{Valence}

Each individual appreciates the final outcome that employees achieve differently. This value depends on their own basic needs. As such, figuring out what an employee's beliefs and what his personal needs are is a good idea for an organization. One might prefer money while another might prefer more days off.

\section{Individual factors}

Individual factors play a major role in achieving goals and employee behavior. Each individual effort, performance and motivation is interconnected. Vroom believes that a positive correlation between effort and performance is necessary to better motivate workers.

\section{Perception}

In Vroom's Expectancy Theory, perception is an important factor. An organization should feel that as an employer, it gives its staff all they need to motivate them sufficiently. The incentive principle of Vroom's Expectancy is not always about the personal interest of the worker in bonuses. It's also about the associations that employees have in terms of their performance and the outcome.

\section{RESULTS (IN LIGHT OF CAUSE AND EFFECT)}

Need to work on employee's behavior and performance to bring the level of win-win. The reason require for performance appraisal is to motivate the employee behavior. Performance appraisal as a motivational tool that can be used to enhance the motivation. It is necessary for staff sustainability [4].

The use of performance appraisal has instance been criticized for the reward of win-lose results as opposed to win-win. The effect of performance appraisal is to increase the interest of employee in that organization progress. The inspiration of employees at work appears through their determination to use their knowledge and skills efficiently to achieve the desired organizational goals in terms of their satisfaction and 
needs. Motivation plays a significant role in driving an organization's progress. There are many key factors that can improve employees ' devotion to an organization. The factors included wages and salaries, job security, promotion and bonuses [5].

Rewards are also some of the key strategies to strengthen the motivation of employees to use their best capabilities to develop innovative ideas that could improve organizational performance financially or nonfinancially. As a result, employees will show a high degree of effort and are likely to devote their focus to performing tasks when they believe that management will reward these efforts $[6,7]$.

\section{DISCUSSION}

In all public and private organizations, motivation plays a major role. They can't run and can't achieve their goals without motivating their employee's organizations. In today's highly competitive environment in organizations where the management of the workforce has gained a lot of attention and importance, where different organizations not only achieve competitive advantage but also high quality, performance satisfaction. One of the key aspects of workforce management is performance assessment, which is used not only for assessment purposes, but also for compensation, promotion, and management training in modern organizations [8].

Formal employee appraisal is a human resource management tool which is also used in other organization such as, personal planning, education, and reward. A study which was conducted in Czech Republic that agriculture organization apply selected methods to access the performance of all employee. One important function of performance appraisal is to provide input for reward decision. There is a relationship between methods of appraisal based on predefined goal and personal planning although the survey outcomes clearly show that outcomes of formal appraisal are most frequent used in area of reward $(92.7 \%)$ [9].

Chintallo and Mahadeo [10] revealed that the issue of employee motivation is faced by all organizations, including the public or private sector. Employee productivity refers to the ability to achieve significant results that are determined by comparing the overall results with the expectations [11]. The degree of efficiency of an employee that ultimately leads to successful organizational results is a key indicator of organizational success that should be given more importance as it measures an organization's competitive power [12]. Recent research has shown that motivation of employees is one of the key factors influencing employee productivity. The motivation of employees is closely linked with the productivity level [13]. In addition, Srivastava and Barmola [11] have shown that motivation is very important to enhance employee organizational commitment, resulting in higher productivity levels.

\section{CONCLUSION}

In order to provide the correct output for example performance to the organization, performance appraisal is an important tool. An employee knows his strength and weakness through performance appraisal and can consolidate his strong area and improve his weakness.

The appraisal process or system should be broad in nature. Performance appraisal or management takes time and commitment from all involved. Performance appraisal system encourages the employee to perform well. Performance appraisal system is connected with the training and development needs of the employee. It helps the employee to give best output for the organization.

\section{RECOMMENDATIONS}

The study recommends that incentives such as financial and non-monetary should be made available or offered to employees. Organization should therefore ensure that the staff is motivated because the incentives play an important role in one's life and influence their success towards achieving the goal. Employees should evaluate their own performance and made an effort to increase productivity [14].

\section{REFERENCES}

1. Van Dijk, D., \& Schodl, M. M. (2015). Performance Appraisal and Evaluation. International Encyclopedia of the Social \& Behavioral Sciences, 716-721.

2. Karak, S., \& Sen, K. (2019). Performance Appraisal of Employees: A Literature Review. International Journal of Research and Analytical Reviews, doi: 2348-1269.

3. Anderson, N., Potočnik, K., \& Zhou, J. (2014). Innovation and Creativity in Organizations. Journal of Management, 40(5), 1297-1333.

4. Brown, T. C., O'Kane, P., Mazumdar, B., \& McCracken, M. (2018). Performance Management: A Scoping Review of the Literature and an Agenda for Future Research. Human Resource Development Review, 18(1), 47-82.

5. Zameer, H., Ali, S., Nisar, W., \& Amir, M. (2014). The impact of the motivation on the employee's performance in beverage industry of Pakistan. International Journal of Academic Research in Accounting, Finance and Management Sciences, 4(1), 293-298.

6. Aktar, S., Sachu, M. K., \& Ali, M. E. (2012). The impact of rewards on employee performance in commercial banks of Bangladesh: An empirical study. IOSR Journal of Business and Management, 6(2), 9-15.

7. Kawara, P. (2014). Effects of reward systems on employee productivity in Catholic University of 
Eastern Africa. International Journal of Recent Research in Commerce Economics and Management, 1(2), 1-4.

8. Hamidi, S. M. (2019). Performance Appraisal and Its Effects on Employees Motivation: A Case Study of Afghan Wireless Communications in Kabul. Available at SSRN 3426851.

9. Venclová, K., Salková, A., \& Kolácková, G. (2013). Identification of employee performance appraisal methods in agricultural organizations. Journal of Competitiveness, 5(2).

10. Chintalloo, S., \& Mahadeo, J. D. (2013). Effect of motivation on employees' work performance at Ireland Blyth Limited. In proceedings of 8th Annual London Business Research Conference Imperial College, London, UK, 8-9.

11. Srivastava, S. K., \& Barmola, K. C. (2012). Role of motivation in higher productivity. Management Insight, 7(1).
12. Hanaysha, J. (2016). Testing the effects of employee empowerment, teamwork, and employee training on employee productivity in higher education sector. International Journal of Learning and Development, 6(1), 164-178.

13. Osabiya, B. J. (2015). The effect of employees' motivation on organizational performance. Journal of Public Administration and Policy Research, 7(4), 62-75.

14. Tenga, M. J. (2014). The role of rewards on staff performance at National Bank of Commerce (Doctoral dissertation, Mzumbe University).

15. alloo, S., \& Mahadeo, J. D. (2013). Effect of motivation on employees' work performance at Ireland Blyth Limited. In proceedings of 8th Annual London Business Research Conference Imperial College, London, UK, 8-9. 